\begin{tabular}{lr}
\hline Jurnal Abdimas llmiah & JURNAL ABDIMAS ILMIAH CITRA BAKTI \\
Citra Bakti & Volume 1, Nomor 2, November 2020 \\
(JAICB) & ISSN 2721-9178 \\
\hline
\end{tabular}

\title{
PELAKSANAAN PROGRAM BIMBINGAN BELAJAR BAHASA INGGRIS "ENGLISH IS FUN" SEBAGAI CARA UNTUK MENINGKATKAN KEMAMPUAN BERBICARA ANAK-ANAK DALAM MENGUASAI BAHASA INGGRIS DI SD
}

\author{
Maria Desidaria Noge ${ }^{1)}$, Maria Patrisia Wau²), Renata Rita Rosana Lado ${ }^{3)}$ \\ 1,2,3) Program Studi Pendidikan Guru Sekolah Dasar \\ STKIP Citra Bakti
}

${ }^{1)}$ ennynoge@gmail.com, ${ }^{2)}$ mariapatrisiawau@gmail.com, ${ }^{3)}$ renatalado@gmail.com

\begin{abstract}
Histori artikel
Received:

16 Oktober 2020

Accepted:

26 November 2020

Published:

30 November 2020

Abstrak

Kegiatan pengabdian masyarakat yang dilakukan secara berkelompok ini merupakan kegiatan pendampingan yang bertujuan untuk melaksanakan kegiatan bimbingan belajar bahasa Inggris English is Fun sebagai cara untuk meningkatkan kemampuan anak-anak dalam memahami bahasa Inggris. Metode kegiatan pengabdian ini adalah metode ceramah, diskusi, lagu dan permainan, demonstrasi dan unjuk kerja. Hasil kegiatan pengabdian menunjukkan bahwa (1) Pendampingan ini telah mampu menumbuhkan minat dan rasa percaya diri siswa/i di SDI Kolokoa dan semangat yang tinggi dalam mempelajari dan menguasai bahasa Inggris sebagai bahasa internasional. Hal ini tampak dari keantusiasan dan ketekunan peserta kegiatan dalam mengikuti pembelajaran dari awal sampai akhir. (2) Kemampuan siswa/i dalam mempelajari bahasa Inggris terlihat baik. Hal ini ditunjukkan dengan antusiasme dan semangat siswa dalam mempelajari materi yang diberikan. (3) Pihak sekolah yakni kepala sekolah, wakil kepala sekolah dan para guru serta pegawai di SDI Kolokoa sangat antusisas dengan pelaksanaan pendampingan ini. Di sisi lain, kegiatan ini membawa dampak yang sangat signifikan untuk membantu siswa mempelajari dan menguasai bahasa Inggris dengan baik. Tindak lanjut dari pelaksanaan kegiatan ini adalah pelaksanaan bimbingan belajar bahasa Inggris secara terprogram di setiap semester. Berdasarkan hasil kegiatan maka dapat disimpulkan bahwa pelaksanaan bimbingan belajar bahasa Inggris "English is Fun" sebagai cara untuk meningkatkan kemampuan anak-anak dalam memahami bahasa Inggris dapat terlaksana dengan baik.
\end{abstract}

Kata-kata Kunci: bimbingan belajar, bahasa inggris, english is fun 
Abstract. This community service activity conducted in groups is a mentoring activity that aims to carry out English is Fun English learning guidance activities as a way to improve children's ability to understand English. This method of devotional activity is a method of lectures, discussions, songs and games, demonstrations and rallies. The results of the devotional activities show that (1) This mentoring has been able to foster the interest and confidence of students in SDI Kolokoa and a high spirit in learning and mastering English as an international language. This is apparent from the enthusiasm and perseverance of the participants in following the learning from start to finish. (2) Students' ability to learn English looks good. This is demonstrated by the enthusiasm and passion of students in studying the materials provided. (3) The school principal, vice principal and teachers and employees at SDI Kolokoa are very concerned with the implementation of this assistance. On the other hand, this activity has a very significant impact to help students learn and master English well. The follow-up to the implementation of this activity is the implementation of programmatic English learning guidance in each semester. Based on the results of the activities, it can be concluded that the implementation of English is Fun learning guidance as a way to improve children's ability to understand English can be done properly.

Keywords : learning guidance english learning, english is fun

\section{PENDAHULUAN}

Di zaman sekarang yang semakin hari semakin maju, mulai dari kemajuan teknologi, pendidikan, kebudayaan yang berkembang, merupakan tantangan tersendiri bagi individu. Apalagi semenjak munculnya program baru yaitu AFTA yang memungkinkan warga asing untuk bekerja di Indonesia, dan warga Indonesia yang diperbolehkan untuk bekerja di negara lain, maka daripada itu tidak hanya sekedar kecakapan dalam bekerja, tetapi individu terutama masyarakat Indonesia harus mampu berbahasa Inggris dengan baik (Derita dkk., 2015).

Bahasa Inggris bukanlah suatu penambah dalam kehidupan, tetapi sudah masuk kewajiban, tanpa kemampuan berbahasa Inggris yang baik, tanpa adanya kecakapan dalam berbahasa Inggris, dan tanpa adanya pengetahuan yang baik berbahasa Inggris, maka seseorang akan mengalami berbagai macam kesulitan dalam mencapai kesuksesan. Melihat pentingnya bahasa dalam berkomunikasi antar sesama manusia di dunia, maka penguasaan bahasa tidak terbatas hanya pada bahasa lbu ataupun bahasa Indonesia saja, melainkan harus menyesuaikan dengan perkembangan global, dimana pendidik maupun peserta didik dapat menggunakan Bahasa Inggris yang merupakan bahasa Internasional atau bahasa trendsetter di seluruh dunia (Noge, M.D., dkk, 2020). Maka dari itu pembelajaran bahasa Inggris harus dibelajarkan sejak dini, terutama anak-anak karena dengan mengadakan program bimbingan belajar seperti ini anak akan termotivasi untuk belajar bahasa Inggris. Menurut Harmer (2007b), semakin dini usia seseorang diperkenalkan dengan bahasa target, semakin cepat dan semakin bagus penguasaan dan pemerolehan anak terhadap bahasa yang dipelajari.

Dalam kegiatan Pengabdian Mayarakat ini, bahasa Inggris dijadikan sebagai bidang ilmu yang akan diabdikan, karena bahasa Inggris itu sangatlah penting sebagaimana yang telah dijelaskan sebelumnya, selain itu, pelaksana dari kegiatan Pengabdian Masyarakat ini adalah individu yang menyukai dan berkompeten di bidang ilmu bahasa Inggris. 
Salah satu wadah di mana seseorang mendapatkan kesempatan untuk belajar bahasa Inggris adalah di sekolah. Pada umumnya, pembelajaran bahasa Inggris diajarkan hanya di kelas VI saja. Strategi yang digunakan guru dalam pembelajaran bahasa Inggris juga belum maksimal sehingga siswa belum mampu memahami materi bahasa Inggris dengan baik. Bahan ajar yang tersedia pun masih sangat minim. Berdasarkan hasil observasi dan wawancara yang dilakukan bersama dengan guru SDI Kolokoa, ditemukan bahwa pembelajaran bahasa Inggris belum dioptimalkan secara baik dan siswa belum memiliki kosakata yang cukup untuk berbicara dalam bahasa Inggris. Hal lain yang ditemukan juga ialah penggunaan bahasa Inggris belum terasa menyenangkan dan metode yang digunakan juga masih sangat kurang karena kekurangan sumber daya manusia yang memiliki bidang keahlian bahasa Inggris. Siswa menjadi malas dan tidak mempunyai motivasi untuk belajar bahasa Inggris. Padahal seperti kita ketahui bahwa penggunaan songs dan games sangatlah bermanfaat bagi siswa dan tentunya mereka akan bersemangat dan senang untuk belajar.

Didasari pada problematika yang dialami di atas, maka penulis ingin memfasilitasi dan membantu anak-anak untuk mempelajari bagaimana penggunaan bahasa Inggris yang menyenangkan, interaktif, dan tepat bagi anak-anak. Program bimbingan belajar ini tentunya akan sangat bermanfaat baik bagi siswa. Bagi siswa, hasil dari program ini akan meningkatkan antusiasme belajar mereka sebagai langkah awal untuk menguasai bahasa Inggris dengan baik.

Telah diketahui bahwa bahasa Inggris merupakan bahasa Internasional yang digunakan hampir di seluruh negara di dunia ini. Bahasa Inggris harus sudah mulai diperkenalkan pada anak sejak dini, termasuk pada anak sekolah dasar. Pada anak sekolah dasar, bahasa Inggris dapat dipelajari melalui kegiatan yang menyenangkan, sehingga anak mempunyai minat untuk belajar bahasa Inggris. Di SDI Kolokoa, kecamatan Jerebuu, belum ada kegiatan/ pembelajaran bahasa Inggris. Di sekolah ini, penerapan pembelajaran belum dilaksanakan secara berkelanjutan karena penerapan pembelajaran bahasa Inggris hanya diterapkan sebagai mata pelajaran muatan lokal saja.

Tujuan kegiatan pengabdian masyarakat ini adalah: menghilangkan persepsi negatif siswa/i sekolah dasar yang berpendapat bahwa bahasa Inggris itu membosankan dan tidak menyenangkan, memberikan ilmu pengetahuan kepada masyarakat luas, terutama anakanak dalam meningkatkan kemampuan berbahasa Inggris, dan membantu anak-anak untuk mampu berbicara berbahasa inggris dengan baik. Kegiatan Pengabdian kepada Masyarakat yang diajukan adalah Pelaksanaan Program Bimbingan Belajar Bahasa Inggris "English Is Fun" di Kecamatan Jerebuu Sebagai Cara Untuk Meningkatkan Kemampuan Anak-Anak dalam Memahami Bahasa Inggris. 


\section{METODE PELAKSANAAN}

Kegiatan ini akan dilaksanakan di SDI Kolokoa, Kecamatan Jerebuu. Kecamatan Jerebuu merupakan salah satu kecamatan yang ada di Kabupaten Ngada, Flores, propinsi Nusa Tenggara Timur. Kecamatan ini terletak di sebelah selatan kabupaten Ngada dan terdiri dari 6 desa.

Sebagaimana telah dipaparkan pada bagian pendahuluan, anak-anak belum dapat menggunakan bahasa Inggris secara efektif dan efisien. Kurangnya minat dan rasa percaya diri anak dalam memepelajarai bahasa Inggris juga menjadi persoalan besar dalam mengembangkan dan menguasai bahasa Inggris. Kegiatan ini ditempuh dengan langkahlangkah pemecahan masalah sebagai berikut. (1) Tim pelaksana merumuskan rancangan materi yang akan disajikan dalam kegiatan ini beserta model pelatihan yang bisa dilakukan.

(2) Peserta kegiatan diajak untuk berpartisipasi aktif melakukan keterlibatan langsung dalam memperoleh pengalaman, misalnya mempraktekkan bahasa Inggris yang menyenangkan dengan songs dan games yang telah diberikan oleh pemateri. Peserta pelatihan juga diberi kesempatan untuk menciptakan sendiri songs dan games yang sesuai dengan karakteristik anak agar pembelajaran lebih bermakna dan bersemangat. Songs dan games adalah strategi yang sedapat mungkin akan menciptakan suasana belajar yang menggembirakan anak dan membuat anak tidak merasa jenuh dalam belajar. Ellis (1994) menyatakan bahwa melihat kecenderungan anak pada lagu, sajak dan bermain, maka hal-hal tersebut bisa dijadikan sarana untuk belajar. (3) Peserta pelatihan diajak berdiskusi tentang pengalaman dan kendala-kendala yang dialami dalam mempelajari bahasa Inggris serta kemungkinan langkah-langkah yang dapat dilakukan untuk dalam bentuk yang sederhana sebagai pemicu tumbuhnya keberanian dan percaya diri anak-anak.

Dalam realisasinya, langkah-langkah pemecahan masalah tersebut dapat dikemukakan berikut ini. (1) Pada tahap ini persiapan sarana dan prasarana yang dibutuhkan dalam kelancaran program "English Is Fun" sama seperti proses belajar pembelajaran, dibutuhkan sarana dan prasarana yang memadai dalam pelaksanaannya, diantaranya: ATK, Kursi belajar, dan meja belajar

Kegiatan ini dilangsungkan satu kali yakni pada tanggal 26 Agustus 2019 bertempat di ruang kelas SDI Kolokoa. Adapun rancangan susunan acara sebagai berikut.

1) Kegiatan akan dimulai dengan interaksi antara tim pelaksana dengan peserta kegiatan untuk melakukan persiapan dan pembagian materi.

2) Kegiatan dilanjutkan dengan doa.

3) Berikutnya adalah kegiatan inti yakni pemaparan materi oleh narasumber dari STKIP Citra Bakti 
4) Sesi berikutnya, pembagian kelompok belajar. Satu kelompok terdiri atas 4 orang

5) Sesi selanjutnya adalah istirahat untuk menikmati makan siang selama 30 menit.

6) Penguatan materi di dalam kelompok bersama pendamping

7) Presentasi materi dari setiap kelompok dengan metode yang variatif dan menyenangkan

8) Doa

9) Penutup

Sejalan dengan cara pemecahan masalah yang ditempuh, maka terdapat sejumlah metode yang diterapkan dalam kegiatan ini. Metode yang digunakan dalam kegiatan ini adalah metode ceramah, diskusi, lagu dan permainan, demonstrasi dan unjuk kerja.

Tahap pertama, metode ceramah digunakan untuk menjelaskan dan memberi pemahaman tentang teori-teori, prinsip-prinsip dan cara mempelajari bahasa Inggris melalui pemberian contoh-contoh yang menyenangkan dan sesuai dengan karakteristik siswa. Tahap kedua yakni diskusi di mana peserta diberi kesempatan untuk berdiskusi diikuti dengan tanya jawab jika ada hal-hal yang masih diragukan dan belum dipahami. Ketiga metode demonstrasi, yaitu di hadapan para peserta diperagakan cara berbicara dengan menggunakan bahasa Inggris dalam bentuk percakapan sederhana. Tahap keempat, peserta diminta atau ditugaskan untuk menciptakan masing-masing satu percakapan sederhana yang menarik, lagu dan permainan. Selama peserta mengerjakan tugas, tim pelaksana melakukan monitoring. Tahap keempat, tugas peserta mengkomunikasikan dan mempresentasikan hasil diskusi kelompok untuk mendapatkan masukan-masukan dari peserta lain maupun dari narasumber.

\section{HASIL DAN PEMBAHASAN}

\section{Hasil}

Kegiatan pengabdian masyarakat yang dilakukan secara berkelompok ini merupakan kegiatan pendampingan yang bertujuan untuk melaksanakan kegiatan bimbingan belajar bahasa Inggris English is Fun sebagai cara untuk meningkatkan kemampuan anak-anak dalam memahami bahasa Inggris. Pendampingan Pelaksanaan Program Bimbingan Belajar Bahasa Inggris "English Is Fun" di Kecamatan Jerebuu Sebagai Cara Untuk Meningkatkan Kemampuan Anak-Anak dalam Memahami Bahasa Inggris bagi siswa/siswi sekolah dasar ini diselenggarakan pada tanggal 26 Agustus 2019, bertempat di SDI Kolokoa Desa Tiworiwu II, Kecamatan Jerebuu. Peserta pelatihan berjumlah 45 orang yang merupakan siswa/i SDI Kolokoa kecamtan Tiworiwu II Kabupaten Ngada. Narasumber dalam kegiatan ini adalah dosen STKIP Citra Bakti Ngada program studi PGSD dan mahasiswa UKM English Club dijabarkan sebagai berikut. 


\begin{tabular}{clc}
\hline No & \multicolumn{1}{c}{ Nama } & NIDN/NIM \\
\hline & & \\
1 & Maria Desidaria Noge, M. Pd & 0823058801 \\
\hline 2 & Maria Patrisia Wau, SE., M. Pd & 0821038202 \\
\hline 3 & Anastasia Ndelos Jawa & 201705001 \\
\hline 4 & Roswita Margarit Wonga & 201706010 \\
\hline 6 & Antonia Jelaha & 201802003 \\
\hline 7 & Hilaria Sanse & 201802011 \\
\hline 8 & Maria Ansilia Bupu & 201705005 \\
\hline 9 & Renata Rita Rosana Lado & 201802033 \\
\hline
\end{tabular}

Pelatihan dilaksanakan selama satu hari dimulai pukul 09.00 s.d 14.00 WITA. Dari pukul 09.00-14.00 Wita, sapaan awal dari panitia serta menyanyikan lagu Indonesia Raya oleh seluruh hadirin yang hadir dalam kegiatan tersebut. Kemudian dilanjutkan acara pembukaan berupa sambutan Ketua pengabdian kepada masyarakat STKIP Citra Bakti yang disampaikan oleh Maria Desidaria Noge, M. Pd dan dilanjutkan oleh Maria Patrisia Wau, SE., M. Pd sekaligus membuka acara kegiatan pelatihan Pendampingan Pelaksanaan Program Bimbingan Belajar Bahasa Inggris "English Is Fun" di Kecamatan Jerebuu Sebagai Cara Untuk Meningkatkan Kemampuan Anak-Anak dalam Memahami Bahasa Inggris di SDI Kolokoa Kabupaten Ngada. Selesai acara pembukaan, pemateri memperkenalkan diri kepada peserta pelatihan. Proses interaksi penyaji - peserta baru dimulai pukul 10.15 wita.

\section{Pembahasan}

Kegiatan terlaksana dalam bentuk berikut ini.

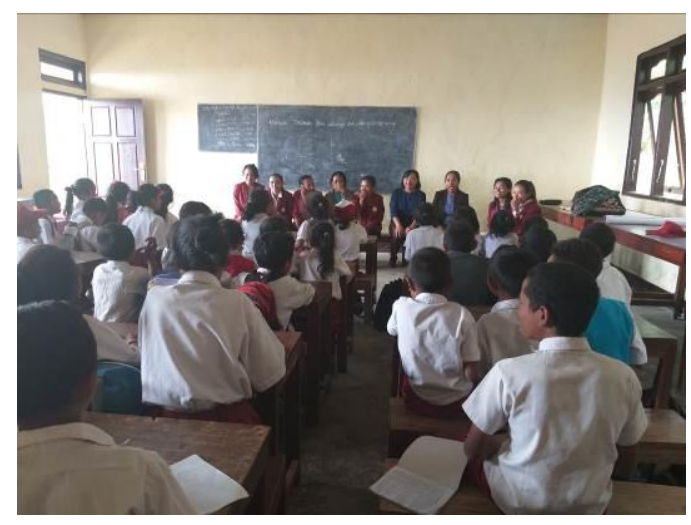

\section{Gambar 1. Siswa Mendengarkan Penjelasan dari Tim Kegiatan Pengabdian}

(1) Penyaji menyajikan materi sajian awal tentang materi-materi bahasa Inggris sederhana antara lain: Greeting and Leave-Taking, Self Introduction,. Materi diberikan oleh penyaji secara berkelompok dan bergantian. Setiap materi yang disampaikan berisi lagu (songs) 
dan permainan (games) untuk menumbuhkan semangat dan antusiasme siswa/i dalam belajar bahasa Inggris.

(2) Sesi berikutnya, peserta pelatihan diberikan kesempatan untuk bertanya menyampaikan hal-hal yang belum dipahami dan bertukar pengalaman terkait kendala-kendala yang pernah dialami dalam pembelajaran bahasa Inggris. Pertanyaan diajukan oleh bapak dan ibu guru yang hadir dalam pelatihan di sesi kedua. Penyaji langsung menanggapi setiap pertanyaan yang disampaikan bapak ibu guru. Dalam hal ini tampak partisipasi peserta sangat baik. Mereka sangat antusias dalam mengikuti seluruh materi yang diberikan dan sangat senang bernyanyi dan melakukan permainan.

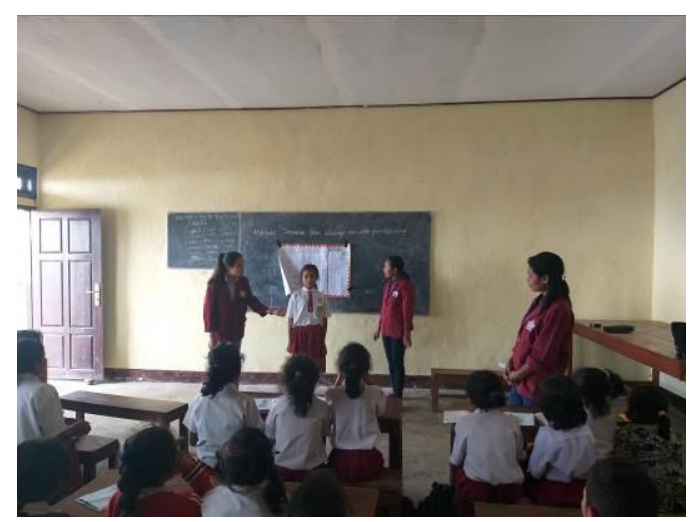

\section{Gambar 2. Peserta Kegiatan Melakukan Demonstrasi di Depan Kelas}

(3) Selanjutnya, jam 12.00 istirahat

(4) Setelah makan siang, penyaji menyajikan materi sajian awal tentang materi-materi bahasa Inggris sederhana antara lain: Alphabets, Numbers, dan Animals. Materi juga diberikan oleh penyaji secara berkelompok dan bergantian. Setiap materi yang disampaikan berisi lagu (songs) dan permainan (games) untuk menumbuhkan semangat dan antusiasme siswa/i dalam belajar bahasa Inggris. Hal ini terlihat dari bagaimana siswa begitu bersemangat untuk mendengarkan materi dan mengikuti kegiatan dengan penuh keceriaan.

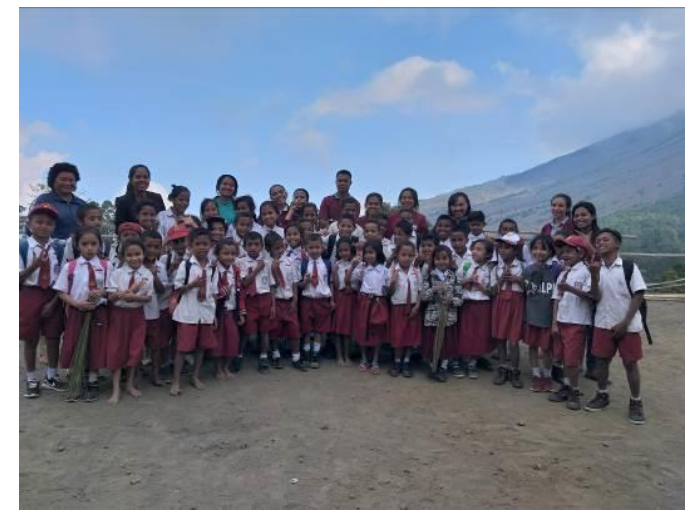

Gambar 3. Foto Bersama Setelah Kegiatan 
(5) Di akhir kegiatan, pemateri memberikan penguatan-penguatan kepada siswa/i. Kegiatan pengabdian ini diakhiri dengan foto bersama tim pengabdian dan peserta kegiatan beserta guru di SDI Kolokoa.

\section{KESIMPULAN}

Simpulan yang dapat ditarik dari paparan di depan adalah sebagai berikut. (1) Pendampingan ini telah mampu menumbuhkan minat dan rasa percaya diri siswa/i di SDI Kolokoa dan semangat yang tinggi dalam mempelajari dan menguasai bahasa Inggris sebagai bahasa internasional. Hal ini tampak dari keantusiasan dan ketekunan peserta kegiatan dalam mengikuti pembelajaran dari awal sampai akhir. (2) Kemampuan siswa/i dalam mempelajari bahasa Inggris cukup baik. Hal ini terlihat dari keaktifan siswa dalam menjawab pertanyaan dan melakukan demonstrasi. (3) Pihak sekolah yakni kepala sekolah, wakil kepala sekolah dan para guru serta pegawai di SDI Kolokoa sangat antusisas dengan pelaksanaan pendampingan ini. Mereka sangat mendukung para siswanya untuk mempelajari bahasa Inggris. Hal ini tampak dari semangat yang luar biasa dari para siswa/i dalam diskusi dan ketika diberi kesempatan untuk berbicara mereka sangat senang dan penuh percaya diri.

\section{DAFTAR PUSTAKA}

Derita, D., Montanesa, D., Wahyuni, R. (2015). Mengadakan program bimbingan belajar bahasa inggris "english is not expensive". Di kota padang sebagai cara untuk meningkatkan keefektifan layanan bimbingan kelompok. Usulan program kreatifitas mahasiswa sebagai syarat dalam lomba karya ilmiah nasional ppipm-unp: Universitas Negeri Padang

Ellis, R. (1994). Second language acquisition. Oxford: OUP.

Harmer, J. (2007b). The practice of english language teaching. Essex, England: Pearson Education Limited.

Noge, M., Tegu, Y., \& Kaka, P. (2020). Model pembelajaran kooperatif tipe inside-outside circle dalam pembelajaran bilingual terhadap hasil belajar siswa. Jurnal Kependidikan: Jurnal Hasil Penelitian dan Kajian Kepustakaan di Bidang Pendidikan, Pengajaran dan Pembelajaran, 6(3), 451-459. 